\title{
小児の鼻汁から得られた検出菌の検討
}

\author{
千葉県立衛生短期大学栄養学科，*千葉県こども病院耳鼻咽喉科
}

工 藤 典 代, 有本 友希子*, 仲 野 敦子*

\section{Bacteriology of Nasal Discharge in Children}

\author{
Fumiyo Kudo, Yukiko Arimoto*, Atsuko Nakano* \\ Department of Nutrition, Chiba College of Health Science, Chiba \\ *Division of Otorhinolaryngology, Chiba Children's Hospital, Chiba
}

Nasal discharge in 34 children under the age of 10 years was bacteriologically studied, who visited our department in 2006. Specimens were collected from middle meatus, whenever possible, for bacteriological identification and susceptibility testing.

We recovered 74 bacterial strains from 34, but no pathogens in 3 patients. The rate of strains was 31.1\% (23 strains) for H. influenzae, 31.1\% for S. pneumoniae, 23.0\% (17 strains) for M. catarrhalis, 8.1\% (6 strains) for S. aureus, and 1.4\% (1 strain each) for Pseudomonas aeruginozae and S. milleli. Pathogen overlap was observed involving 1 strain in 7 patients (21\%), 2 in $8(24 \%), 3$ in $14(40 \%)$ and 4 in 2 (6\%). At least one of such common pathogens as H. influenzae, S. pneumoniae, and M. catarrhalis was detected in 30 patients (88.2\%). In 20 patients (58.9\%) at least one penicillin-resistant bacteria was detected. M. catarrhalis was included in penicillin-resistant bacteria because about $99 \%$ of $M$. catarrhalis may produce beta-lactamase.

According to our findings, susceptibility of $H$. influenzae was $43.0 \%$ for beta-lactamase-negative ampicillinsusceptible strain (BLNAS), 8.7\% for low beta-lactamase-negative ampicillin-resistant strain (low BLNAR), $38.9 \%$ for BLNAR, and 7.5\% for beta-lactamase producing ampicillin-resistant strain (BLPAR). Susceptibility of S. pneumoniae was $40.0 \%$ for penicillin-susceptible $S$. pneumoniae (PSSP), 43.6\% for penicillin-intermediate $S$. pneumoniae (PISP), and $16.4 \%$ for penicillin-resistant S. pneumoniae (PRSP).

Our study demonstrated the key importance of antibiotic therapy for rhinosinusitis in children due to the overlap of pathogenic bacteria and the existence of antibiotics-resistant strains.

\footnotetext{
Key words：鼻副鼻腔炎, 細菌培養検査, 耐性菌, 薬剤感受性, 抗菌薬治療 rhinosinusitis, bacteriology culture, penicillin resistant $S$. pneumoniae, $\beta$-lactamase non-producing ampicillin resistant $H$. influenzae, antibacterial therapy
}

\section{はじめに}

急性中耳炎では診療ガイドラインが公表され，臨床症 状と鼓膜所見から具体的な治療法の推奨が行われてい る。一方，小児の鼻副鼻腔炎では各担当医が経験に基づ き治療法を決定している。われわれは水性以外の鼻汁が あれば何らかの感染症と考えてよいのか, 病原菌が検出 されれば抗菌薬投与が必要になるのか否か, 日常診療上
常に治療の選択を迫られてきた。一方で，鼻汁から検出 される病原菌のうちどの菌を治療対象と考えるのか，未 解決の点が多い。今回, 鼻汁中の細菌培養検査を行うこ とで小児の鼻汁の実態を把握し, 今後の鼻副鼻腔炎治療 のなんらかの手掛かりとなることを期待し，鼻汁からの 検出菌の検討を行ったので報告する。 


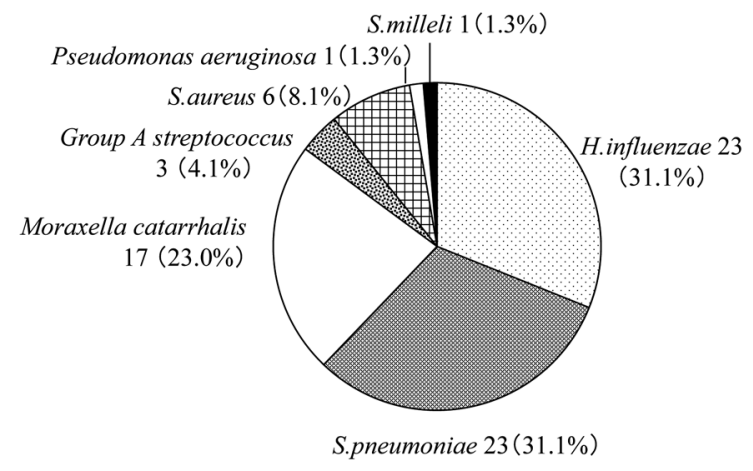

図 1 検出菌の内訳（全74株。数值は検出株数と比率 \%を示す)

\section{I. 対}

対象は2006年に千葉県こども病院耳鼻咽喉科を受診し た症例で，鼻内に鼻汁が認められ，細菌検査を施行した 10歳以下の小児34例である。なお検体として採取した鼻 汁は明らかにアレルギー性が疑われる水性鼻汁を除き， 漿液性, 粘性, 粘膿性, 膿性などすべての性質の鼻汁を 対象とした。

\section{II. 方 法}

小児の鼻汁を栄研のシードスワブ $\gamma 2$ 号を用いてなる ベく中鼻道から採取し, 細菌検査に提出し, 細菌の同定 と微量液体希䣋法による感受性検査を行った。また過去 に1995年と2001年の 2 回，同様の検討を行った結果を 1996年 ${ }^{1)}$ と2003年 ${ }^{2)}$ に報告しており，その結果と比較し た。

なお, Haemophilus influenzae はアンピシリン (ampicillin：ABPC）の感受性と, $\beta$-lactamase 産生の有無, ま た $\beta$-lactamase 産生株ではクラブラン酸（clavulanic acid：CVA）に対する感受性から， $\beta$-lactamase non-producing ampicillin susceptible (BLNAS), $\beta$-lactamase producing ampicillin resistant (BLPAR), $\beta$-lactamase non producing ampicillin resistant (BLNAR), $\beta$-lactamase producing ampicillin clavulanic acid resistant (BLPACR) の 4 種類に分類した。なお BLNAR はABPC の最小発育 阻止濃度（MIC：minimum inhibitory concentration）を $4 \mu \mathrm{g} / \mathrm{ml}$ 以上, low-BLNAR は同様に $2 \mu \mathrm{g} / \mathrm{ml}$ としてい る。

Streptococcus pneumoniae は penicillin G の感受性によ り penicillin susceptible $S$. pneumoniae (PSSP), penicillin intermediately $S$. pneumoniae (PISP), penicillin resistant S. pneumoniae (PRSP) の 3 種に分類した。なおこ れらの分類は米国 CLSI (Clinical and Laboratory Stan-

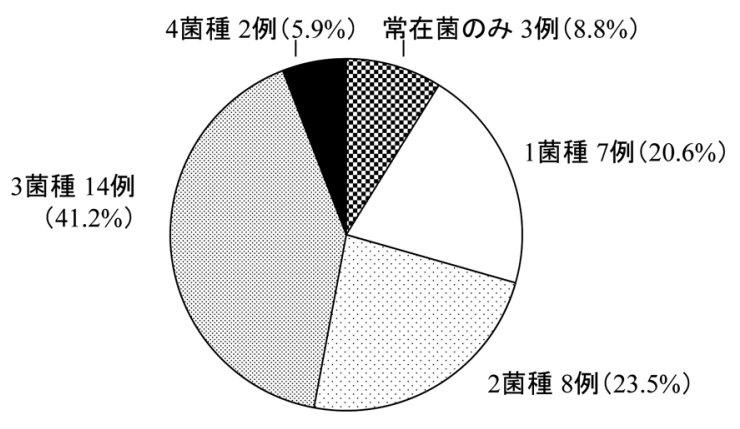

図 2 複数菌検出の状況（全34例, 図の数值は症例数 と比率\%を占めす)

dards Institute）の基準に従った。

また，表皮ブドウ球菌（Staphylococcus epidermidis）， コアグラーゼ陰性ブドウ球菌 (Coagulase-negative staphylococci, CNS), ナイセリア属, ビリダンス群は常在菌と して扱い, 過去の報告と同様, 病原菌には含めていない。

\section{III. 結 果}

対象症例の年齢は生後 1 カ月から 9 歳 11 カ 年齢は 3 歳11力月（中央值 3 歳）であった。病原菌が検 出されたのは34例中 31 例 $(91.2 \%)$ で, 残りの 3 例は CNS のみであった。常在菌を除く検出菌は74株検出された。 菌の内訳を図 1 に示した。インフルエンザ菌と肺炎球菌 が23例に，モラキセラ・カタラーリスが17例に，次い で, 黄色ブドゥ球菌, A 群溶血性連鎖球菌の順に分離頻 度が高かった。インフルエンザ菌, 肺炎球菌, モラキセ ラ・カタラーリスのいずれかが検出されたのは34例 中，30例であった。他の 4 例中 1 例は生後 1 力月児で黄 色ブドウ球菌のみが検出された。

34 例に 74 菌数が検出されたことは一人に複数の菌が検 出されたことになる。対象症例の複数菌検出の状況を図 2 に示した。常在菌のみが 3 例 $(9 \%), 1$ 菌種のみ が 7 例 $(21 \%) ， 2$ 菌種 が 8 例 $(24 \%) ， 3$ 菌種 が14例

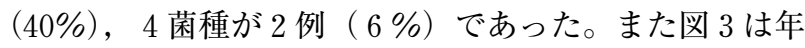
齢別の複数菌検出状況である。複数菌が検出されたの は, 0 歳と 1 歳の 11 例では 5 例 $(46.5 \%)$ であったが, 2 歳以上の 23 例では19例 $(82.6 \%)$ であり，複数菌の検出 率は大きく異なっていた。この割合は $\chi^{2}$ 検定 $\left(\chi^{2}{ }_{0.05(1)}\right)$ で有意差が認められた。

検出された菌のうち感受性検査を施行できた肺炎球菌 の耐性菌の状況を図 4 に, インフルエンザ菌の耐性の状 況を図 5 に示した。肺炎球菌は18株のうち PSSP が 7 株 (38.9\%), PISP が 8 株 (44.4\%), PRSP が 3 株 (16.7\%) であった。インフルエンザ菌は19株中 BLNASが 9 株 (47.4\%), low-BLNAR が 3 株 (15.8\%), BLNARが 6 株 


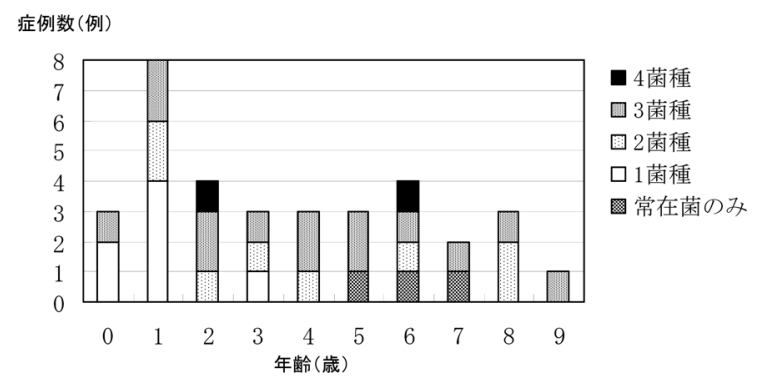

図 3 複数菌検出の年歯別状況

(31.6\%)，BLPARが 1 株 $(5.2 \%)$ であった。困 4，5 のいずれも一番上の棒グラフは参考のため千葉県こども 病院における鼻汁を含めたすべての検体の状況を示し た。なお, 全検体の耐性の状況と耳漏, 鼻汁から得られ た耐性菌化率は有意な差はないことを過去の検討で明ら かにしている゙๋。

\section{N. 考 察}

小児の鼻汁からは主としてインフルエンザ菌，肺炎球 菌，モラキセラ・カタラーリスの 3 種が検出され，この 3 種が 3 大検出菌と考えられる。2001年の検討でもイン フルエンザ菌が $36.6 \%$ ，肺炎球菌が $30.4 \%$ ，モラキセ ラ・カタラーリスが $27.8 \%$ あ゙あ，今回の検討ではそれ ぞれ，31.1\%，31.1\%，23.0\%で同様の傾向を示してい た。図 6 に1991年から過去 3 回にわたって調査した結果 を提示したが，過去 3 回ともこの 3 種で $85 \%$ 以上を占め ている。また 34 例中，これら 3 種のいずれかが検出され た症例は30例で $88.2 \%$ 占めていた。

成人では保富ら ${ }^{4)}$ が20歳以上の成人の急性鼻副鼻腔炎 において，中鼻道から採取した 64 例の検討では 3 大起炎 菌のいずれかが検出されたのは25例（51.0\%）と報告し ている。また急性鼻副鼻腔炎から検出された肺炎球菌と amoxicillin/clavulanate の治療効果について報告した Anon ら $^{5}$ によれば, 肺炎球菌は1156例のうち371 例， $32.9 \%$ に検出されたと報告している。

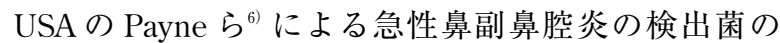
Meta-Analysis では，1990年から2006年までの英文論文 において，副鼻腔から採取した検体から肺炎球菌が $32.7 \%$ ，インフルエンザ菌が31.6\%，黄色ブドウ球菌が $10.1 \%$ ，モラキセラ・カタラーリスが $8.8 \%$ と報告して いる。今回の調査結果と比較すると Payne らの報告は モラキセラ・カタラーリスが少なく，むしろ急性中耳炎 の中耳貯留液 ${ }^{7)}$ と同様の傾向がうかがえた。しかし， Payne らの報告 ${ }^{6)}$ (成人の急性副鼻腔炎を対象にした副 鼻腔からの検出菌であり, かつ肺炎球菌とインフルエン ザ菌の検出率は, 今回の小览の鼻汁中の検出率とほぼ同

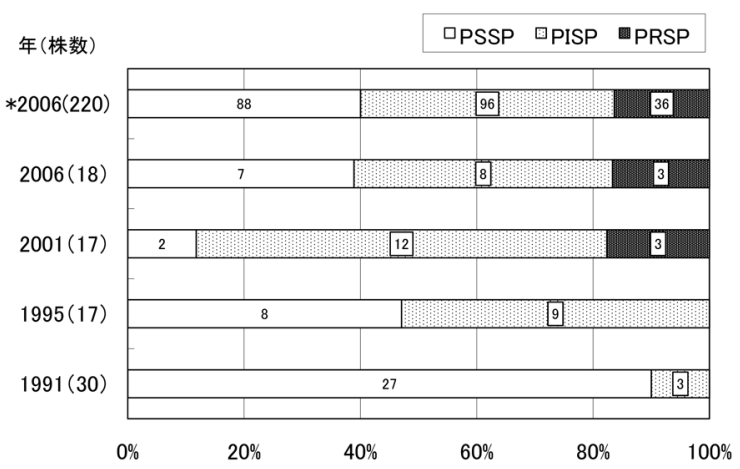

図 4 鼻中から得られた肺炎球菌の耐性状況（* 2006は鼻汁を含めた全検体のデータである。 PSSP : penicillin-susceptible S. pneumoniae, PISP : penicillin-intermediate $S$. pneumoniae, PRSP : penicillin-resistant $S$. pneumoniae)

様であったことは興味深い。

鼻汁から検出される菌は一種類だけではなく複数菌が 検出されることは，以前の調査結果からも判明してお り，急性中耳炎とは異なった特徵である。2001年の66例 70 エピソードの調査では一菌種のみが $32.8 \%$ あ り，57.1\%に複数菌が検出されていた。今回は一菌種が $20.6 \%$ ，複数菌が検出されたのは $70.6 \%$ あった。図 3 に示したように， 2 歳以上の 23 例で複数菌を持っている 例は $82.6 \% ， 1$ 歳以下の 11 例では $45.5 \%$ で， $\chi^{2}$ 検定で 有意差が認められた。 2 歳以上では複数菌の保有が 0,1 歳児と比較し有意に多いと考えられる。

複数菌の検出率について，今回の鼻汁の結果と急性中 耳炎の結果とは検体採取法が異なるため，単純に比較す るのは困難である。すなわち鼻汁が中鼻道から採取され たものであり，急性中耳炎は鼓膜切開を施行し中耳貯留 液を検体としている点が異なっている。急性副鼻腔炎と 急性中耳炎を対比させるならば急性副鼻腔炎は副鼻腔の 穿刺液を検体として比較するのが適切であろう。

今回の検討は急性副鼻腔炎を対象としたものではな く，鼻汁のある小児を対象としたものである。また，鼻 汁は可能な限り中鼻道から検体採取を行っているが，乳 児の場合は中鼻道からの採取は困難で総鼻道からの採取 となっている。小児では rhinosinusitis（鼻副鼻腔炎） と称されるように，多くは鼻炎と副鼻腔炎を明確に鑑別 できる病態ではなく，また特に乳幼児の副鼻腔からの採 取は困難と考えている。水性以外の鼻汁の $91.2 \%$ に病原 菌が検出されたことは小児の鼻副鼻腔炎の実態を知る上 でも重要と考える。

鼻副鼻腔炎の治療を前提に調査結果をみると，一個人 からどのような菌が検出されたか，検出された複数菌の 中ではどの菌を起炎菌と考えるか，また，複数菌のなか 


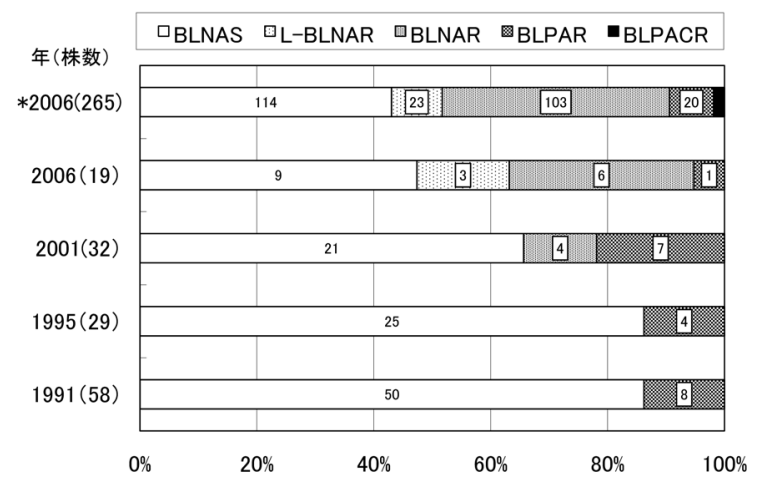

図 5 鼻汁から得られたインフルエンザ菌の耐性状況 （2006は鼻汁を含めた全検体のデータである。 BLNAS : beta-lactamase-negative ampicillin-susceptible, L-BLNAR: low beta-lactamase-negative ampicillin-resistant, BLNAR : beta-lactamasenegative ampicillin-resistant, BLPAR : beta-lactamase producing ampicillin-resistant, BLPACR : beta-lactamase producing ampicillin-clavulanate resistant)

口Hi 回.p ロ M.c 图GAS 因黄色ブ菌 口緑膿菌 Milleli

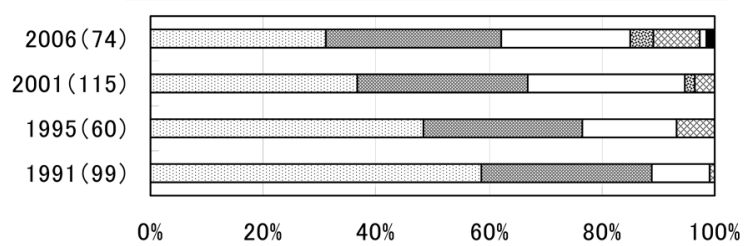

図 6 鼻汁から検出された細菌の内訳：過去のデー夕 (H.i：インフルエンザ菌, S.p : 肺炎球菌, M.c： モラキセラ・カタラーリス, GAS：A群溶血性連 鎖球菌, Milleli：ミレリ菌）

に耐性菌が含まれているかどうかが重要と考える。急性 中耳炎では中耳貯留液からは一種類のみ細菌が検出され ることが多く，その菌に対する抗菌薬を選択する。しか し，鼻汁からは複数菌が検出されるため，どの菌を起炎 菌と考えるか，それ以外の菌，たとえば $\beta$ ラクタマー ゼを産生するモラキセラ・カタラーリスは感染に影響を 来していないのか, 診療の場面では判断に苦慮している のが現実である。

一個人が保有している菌の耐性状況をみたのが図 7 で ある。図 7 では PISP と PRSP を肺炎球菌の耐性株, イ ンフルエンザ菌では BLNAS 以外を耐性株として，いず れかの耐性菌を保有している場合を「耐性菌あり」, 検 出菌がすべて感性菌であれば「耐性菌なし」と分類した。 モラキセラ・カタラーリスは $\beta$-lactamase を産生してい ることが多いため，「耐性菌なし」の群でも同時にモラ キセラ・カタラーリスが検出されていた場合は「M.cを 含む」として図示した。このデータからは，34例中11例

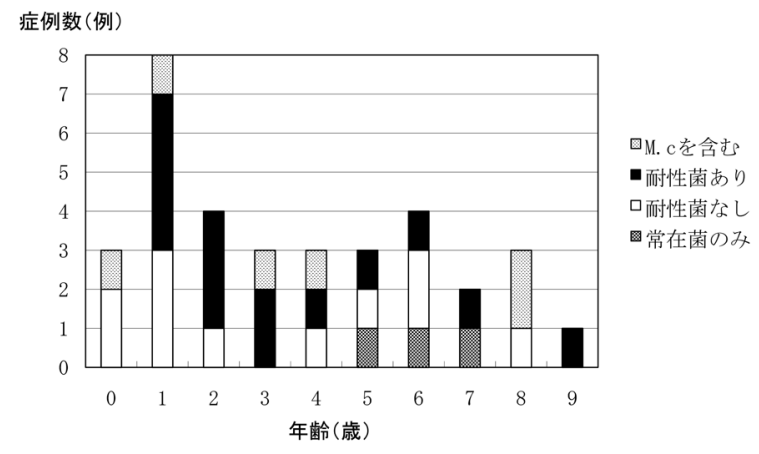

図 7 年齢別, 鼻汁中の耐性菌の状況（M.c：M. catarrhalis)

(32.3\%) には耐性菌はなく，3 例 $(8.8 \%)$ は常在菌の み，14例 $(41.2 \%)$ が何らかの耐性菌を保有しているこ とになる。また 6 例（17.4\%）は耐性菌でない菌と共に モラキセラ・カタラーリスが検出されていた。図 7 では 年齢も示しているが,「耐性菌なし」+「常在菌」群を みると， 0 歳児では 3 例中 2 例 $(66.7 \%) ， 1$ 歳以上で は31例中12例 $(38.7 \%)$ となる。逆に「耐性菌あり」の 群十「モラキセラ・カタラーリスを含む」群をみると 0 歳児では33.3\%，1歳以上は61.3\%となった。この傾向 は抗菌薬治療を考えるうえで，0 歳と 1 歳以上では肺炎 球菌とインフルエンザ菌の耐性菌とモラキセラ・カタラ ーリスの $\beta$-ラクタマーゼ産生について十分な配慮が必 要と考える。

図 4 と図 5 は2006年の肺炎球菌とインフルエンザ菌の 耐性率も示している。2000年の調査 ${ }^{3)}$ で喀痰や髄液など を含めた全検体における耐性菌の比率と鼻汁や耳漏の耐 性菌の比率には $\chi^{2}$ 検定で有意差がなかったことから, 今後鼻汁から得られた肺炎球菌やインフルエンザ菌の耐 性率を考える際には他検体を含めた全検体の耐性率と同 程度と考えることが可能である。今回の調查でも鼻汁か ら得られた肺炎球菌とインフルエンザ菌の耐性率は全検 体の耐性率と同様の傾向があった。経年的には2006年の 肺炎球菌ではPSSPが40\%，PISPが43.6\%，PRSPが $16.4 \%$ と，最も耐性率の高かった2004年よりは耐性化が 減少している。一方，インフルエンザ菌はBLNAS が $43.0 \%$ 年々, 感受性菌が減少の一途をたどり, BLNAR は38.9\%, low-BLNAR $(8.7 \%)$ も含めると $47.6 \%$ が AMPC の MIC が $2 \mu / \mathrm{ml}$ 以上の BLNAR で上昇の一途を たどっている。

複数菌の中で感染症の原因菌はなにか，を同定するこ とはかなり困難だと思われる。また，菌が検出されれば 感染症と考え抗菌薬が必要になるかどうか，という検討 も必要であり, 鼻副鼻腔炎の重症度やその病態をふくめ た今後の検討が必要である。しかし，このような細菌学 
的検討は，感染症と認識していない状態でも，小児の鼻 汁からは複数の病原菌が検出される, という小児の鼻汁 の実態を把握するためには有用であると考える。また， 耐性菌とモラキセラ・カタラーリスのいずれか，あるい は両方が検出率される率が 0 歳と 1 歳以上では $33.3 \%$ と 61.3\%と大きく異なるため，抗菌薬治療を考える際に 「小児急性中耳炎診療ガイドライン」を参考にすれば， 0 歳時には AMPC の通常量，1歳以上には急性中耳炎の 中等症以上と考元，AMPC の高用量，あるいは耐性菌 を考慮した抗菌薬の選択が必要と思われる。

米国における鼻副鼻腔炎に対する治療では “Clinical Practice Guideline : Management of Sinusitis”" ${ }^{8}$ が2001年 に発表されている。これによると軽症，中等症，重症に 分け，重症例には high doseの Amoxicillin/Clavulanate を第一選択薬として挙げている。同様に Novembre ら ${ }^{9)}$ は鼻副鼻腔炎に対する系統的な治療を行うに当たり， 3 大起炎菌を挙げている。さらにインフルエンザ菌とモラ キセラ・カタラーリスは $\beta$-lactamase を産出するために ペニシリン耐性であると述べている。また，前出の “Clinical Practice Guideline: Management of Sinusitis" では，インフルエンザ菌の約 $50 \%$ が $\beta$-lactamase positive とされており，米国では BLPARの比率が高いことが示 唆されている。このような各国の耐性菌の状況の違いか ら，わが国では本邦の菌の保有状態や耐性菌の状況によ り抗菌薬投与を含めた治療を考慮する必要があると考え る。その前に鼻汁から病原菌が検出されれば，感染症と 考え抗菌薬投与を行うべきかどうかの議論と病態の把握 がぜひとも必要である。

\section{まと め}

小児の鼻汁から得られた細菌の検討を行った。インフ ルエンザ菌, 肺炎球菌，モラキセラ・カタラーリスが 3 大検出菌であり, 同一例に複数菌が検出される例が多か った。同一例で検出された菌のいずれかが耐性菌である 可能性は約 6 割であり，2 歳以上は $82.6 \% ， 1$ 歳以下は 45.5\%と年代により差が見られた。鼻汁から菌が検出さ れれば抗菌薬が必要か，という議論は今後の検討が必要 であるが，抗菌薬を投与する場合には複数菌の保有，し かもいずれかの菌が耐性化している可能性が高いことを
考慮する必要がある。

\section{参考文献}

1）宇田川優子, 工藤典代 : 小児鼻 - 副鼻腔炎の細菌学 的検討. 小児耳鼻咽㑨科 $1996 ; 17(1): 48-51$.

2 ）工藤典代，留守卓也：小児鼻・副鼻腔炎の鼻汁から 得られた検出菌の検討。日耳鼻感染症 $2003 ; 21$ (1) $: 80-5$.

3 ）工藤典代, 小林由実, 大楠清文 : 耳漏と鼻汁から検 出されたインフルエンザ菌および肺炎球菌の薬剤耐 性の変化. 小児耳 $2000 ； 21(2) ： 47-52$.

4 ) 保富宗城, 藤原啓次, 宇野芳史, 他：急性鼻副鼻腔 炎に対するgatifloxacinの有効性. 日化療会誌 2008 ; 56 (1) : 7-15.

5 ) Anon JB, Ferguson B, Twynholm M, et al: Pharmacokinetically enhanced amoxicillin / clavulanate $(2,000 / 125 \mathrm{mg})$ in acute bacterial rhinosinusitis caused by Streptococcus pneumoniae, including penicillin-resistant strains. Ear Nose Throat J $2006 ; 85(8): 500-2$.

6 ) Payne SC, Benninger MS : Staphylococcus aureus is a major pathogen in acute bacterial rhinosinusitis : a meta-analysis. Clin Infect Dis 2007; 45 (10) : e121-7.

7 ）西村忠郎，鈴木賢二，小田 恂，他：第 3 回耳鼻咽 喉科領域感染症臨床分離菌全国サーベイランス結果 報告. 日本耳鼻咽喉科感染症誌 $2004 ； 22(1) ： 12-$ 23.

8 ) American Academy of Pediatrics, Subcommittee on Management of Sinusitis and Committee on Quality Improvement : Clinical Practice Guideline : Management of Sinusitis. Pediatrics 2001; $108(3)$ : 798-808.

(2008年 4 月 2 日受稿， 2008 年 7 月 8 日受理)

別刷請求先：工藤 典代

２ 261-0014 千葉市美浜区若葉 2-10-1

千葉県立衛生短期大学栄養学科 